\title{
Effect of age on pharmacokinetics, efficacy, and safety of galcanezumab treatment in adult patients with migraine: results from six phase 2 and phase 3 randomized clinical trials
}

Virginia L. Stauffer ${ }^{1 *}$ D, Ira Turner², Phebe Kemmer', William Kielbasa', Kathleen Day', Martha Port', Tonya Quinlan and Angelo Camporeale ${ }^{3}$

\begin{abstract}
Background: Migraine clinical profile may change with age, making it necessary to verify that migraine treatments are equally safe and effective in older patients. These analyses evaluated the effects of patient age on the pharmacokinetics (PK), efficacy, and safety of galcanezumab for prevention of migraine.

Methods: Analyses included efficacy data from three double-blind phase 3 clinical trials: two 6-month studies in episodic migraine (EVOLVE-1, EVOLVE-2: $N=1773$ ) and one 3-month study in chronic migraine (REGAIN:N = 1113). Patients were randomized 2:1:1 to placebo, galcanezumab $120 \mathrm{mg}$, or galcanezumab $240 \mathrm{mg}$. Safety and PK data included additional phase 2 and phase 3 trials for a larger sample size of patients $>60$ years (range $=18-65$ for all studies). Subgroup analyses assessed efficacy measures, adverse event (AE) occurrence, and cardiovascular measurement changes by patient age group. Galcanezumab PK were evaluated using a population analysis approach, where age was examined as a potential covariate on apparent clearance (CL/F) and apparent volume of distribution (V/F) of galcanezumab.

Results: Numbers of baseline monthly migraine headache days were similar across age groups. There were no statistically significant treatment-by-age group interactions for any efficacy measures, except in episodic migraine studies where older patients appeared to have a larger reduction than younger patients in the number of monthly migraine headache days with acute medication use. Age (18-65) had a minimal effect on CL/F, and no effect on V/ F. Galcanezumab-treated patients $\geq 60$ years experienced no clinically meaningful increases in blood pressure and no increased frequency in treatment-emergent $A E s$, discontinuations due to AEs, serious adverse events (SAEs) overall, or cardiovascular SAEs, compared to age-matched placebo-treated patients.

(Continued on next page)
\end{abstract}

\footnotetext{
* Correspondence: vstauffer@lilly.com

${ }^{1}$ Lilly Research Laboratories, Lilly Corporate Center, Indianapolis, IN, USA

Full list of author information is available at the end of the article
}

(c) The Author(s). 2020 Open Access This article is licensed under a Creative Commons Attribution 4.0 International License, which permits use, sharing, adaptation, distribution and reproduction in any medium or format, as long as you give appropriate credit to the original author(s) and the source, provide a link to the Creative Commons licence, and indicate if changes were made. The images or other third party material in this article are included in the article's Creative Commons licence, unless indicated otherwise in a credit line to the material. If material is not included in the article's Creative Commons licence and your intended use is not permitted by statutory regulation or exceeds the permitted use, you will need to obtain permission directly from the copyright holder. To view a copy of this licence, visit http://creativecommons.org/licenses/by/4.0/ The Creative Commons Public Domain Dedication waiver (http://creativecommons.org/publicdomain/zero/1.0/) applies to the data made available in this article, unless otherwise stated in a credit line to the data. 
(Continued from previous page)

Conclusions: Age (up to 65 years) does not affect efficacy in migraine prevention and has no clinically meaningful influence on galcanezumab PK to warrant dose adjustment. Furthermore, older galcanezumab-treated patients experienced no increases in frequency of AEs or increases in blood pressure compared with age-matched placebotreated patients.

Trial registrations: EVOLVE-1 (NCT02614183, registered 23 November 2015), EVOLVE-2 (NCT02614196, 23 November 2015), REGAIN (NCT02614261, 23 November 2015), ART-01 (NCT01625988, 20 June 2012, ), I5Q-MC-CGAB (NCT02163993, 12 June 2014, ), I5Q-MC-CGAJ (NCT02614287, 23 November 2015, ), all retrospectively registered.

Keywords: Aging population, Elderly, Migraine, CGRP antagonist, Migraine in older adults, Migraine prevention, Migraine prophylaxis, Galcanezumab, Monoclonal antibody

\section{Background}

Galcanezumab is a humanized monoclonal antibody $(\mathrm{mAb})$ that targets calcitonin gene-related peptide (CGRP) and is currently approved for migraine prevention in many countries including the United States and those of the European Union [1, 2]. Galcanezumab is injected subcutaneously once per month and reduces the number of monthly migraine headache days in patients with both episodic and chronic migraine [1-5].

While migraine is most prevalent in people aged 25 to 55 years [6], many people over the age of 55 years also experience migraine attacks [7-9], with the one-year prevalence of migraine among older adults being reported as approximately $10 \%$ [10]. However, diagnosis of migraine typically occurs before the age of 50 years and the prevalence of migraine tends to decrease with age $[10,11]$.

Population pharmacokinetic (PK) analyses are commonly used to understand the influence of age on drug exposure, efficacy, and safety to help guide clinical dosing regimens. A population PK analysis examining the effect of age on apparent clearance (CL/F) and apparent volume of distribution (V/F) of galcanezumab can provide useful data for health professionals in understanding the PK risk of the drug in patients of various ages.

Because aging is associated with cardiovascular changes, resulting in altered blood pressure (BP) and heart rate [12], potential cardiovascular effects of a drug are of increased concern when considering treatment options for an older population. Some migraine medications, such as ergots and triptans, are contraindicated in patients with certain cardiovascular and cerebrovascular conditions, due to their vasoconstrictive effects [13]. As galcanezumab blocks the action of CGRP, which is a potent microvascular vasodilator with a number of physiological roles [14], it is necessary to determine if galcanezumab treatment increases occurrences of cardiovascular-related adverse events or high BP, specifically in older patients.

Furthermore, how migraine is expressed can change with age, and these changes could affect the way a patient responds to medication. A trend towards less severe migraine attack has been reported in patients over 50 years old [15], and migraine profile can change as a person gets older, with some people reporting improvement, some worsening, and some developing a less typical migraine profile $[15,16]$.

The purpose of this analysis was to determine the effects of age on PK, efficacy, and safety of galcanezumab treatment in patients with episodic and chronic migraine.

\section{Methods}

\section{Clinical trials}

The analyses by age used data from six clinical trials, including three phase 3 placebo-controlled, doubleblinded trials, two phase 2 placebo-controlled, doubleblinded trials, and one open-label phase 3 trial. All trials mentioned in this analysis complied with the Declaration of Helsinki and followed the guidelines of the International Conference on Harmonization on Good Clinical Practices and all applicable laws and regulations. Studies were approved by each institution's ethical review board and all trial participants provided written, informed consent prior to enrollment. All trials enrolled patients $\geq 18$ to $\leq 65$ years, who had been diagnosed with migraine for at least 1 year (for episodic migraine only) and prior to the age of 50 years.

Detailed descriptions for the study designs for EVOLVE-1, EVOLVE-2, and REGAIN have been described previously [3-5], as have the additional clinical trials included in the PK and safety populations [17-19]. Key points of the six trials are summarized in Tables 1.

\section{Analyses by age}

Different patient populations and clinical trials were used for the age analyses described in this manuscript (Table 2). Data from the three phase 3 placebocontrolled trials (EVOLVE-1, EVOLVE-2, and REGAIN) were used for baseline comparisons and analyses of efficacy outcomes. Pharmacokinetic analyses included 
Table 1 Clinical trials included in analyses

\begin{tabular}{|c|c|c|c|}
\hline \multicolumn{4}{|l|}{ Phase 3 placebo-controlled trials } \\
\hline & EVOLVE-1 & EVOLVE-2 & REGAIN \\
\hline NCT number & NCT02614183 & NCT02614196 & NCT02614261 \\
\hline $\begin{array}{l}\text { No. of patients randomized and } \\
\text { treated (ITT) }\end{array}$ & 858 & 915 & 1113 \\
\hline Study centers & 90 in US and Canada & $\begin{array}{l}109 \text { in Asia, Europe, North and South } \\
\text { America }\end{array}$ & $\begin{array}{l}116 \text { in Asia, Europe, North and South } \\
\text { America }\end{array}$ \\
\hline Headache frequency & \multicolumn{2}{|c|}{ 4-14 migraine headache days/month (episodic migraine) } & $\begin{array}{l}\geq 15 \text { headache days } / \text { month }{ }^{\mathrm{a}} \text { (chronic } \\
\text { migraine) }\end{array}$ \\
\hline Double-blind & \multicolumn{2}{|l|}{6 months } & 3 months \\
\hline Open label & \multicolumn{2}{|l|}{ None } & 9 months \\
\hline $\begin{array}{l}\text { Additional migraine preventive } \\
\text { medications }\end{array}$ & \multicolumn{2}{|l|}{ Not permitted } & $\begin{array}{l}\text { Stable doses of allowed treatments } \\
\text { permitted }^{\mathrm{b}}\end{array}$ \\
\hline Trial phase & \multicolumn{3}{|l|}{3} \\
\hline PBO-controlled & \multicolumn{3}{|l|}{ Yes } \\
\hline Treatment arms & \multicolumn{3}{|c|}{$\begin{array}{l}\text { GMB } 120 \text { mg with } 240 \text { mg loading dose } \\
\text { GMB } 240 \text { mg } \\
\text { PBO }\end{array}$} \\
\hline Treatment regimen & \multicolumn{3}{|l|}{ Subcutaneous injection every month } \\
\hline \multicolumn{4}{|l|}{ Other clinical trials } \\
\hline & ART-01 & CGAB & CGAJ \\
\hline NCT number & NCT01625988 & NCT02163993 & NCT02614287 \\
\hline $\begin{array}{l}\text { No. of patients randomized and } \\
\text { treated (ITT) }\end{array}$ & 217 & 410 & 270 \\
\hline Study centers & 35 in US & 37 in US & 28 in North America and Europe \\
\hline Headache frequency & $\begin{array}{l}4-14 \text { migraine headache days/ } \\
28 \text { days }\end{array}$ & $\begin{array}{l}4-14 \text { migraine headache days/28 } \\
\text { days }\end{array}$ & $\geq 4$ migraine headache days/month \\
\hline Double-blind & 12 weeks & 12 weeks & none \\
\hline Open label & None & None & 12 months \\
\hline $\begin{array}{l}\text { Additional migraine preventive } \\
\text { medications }\end{array}$ & Not permitted & Not permitted & Not permitted \\
\hline Trial phase & 2 & $2 b$ & 3 \\
\hline PBO-controlled & Yes & Yes & No \\
\hline Treatment arms & $\begin{array}{l}\text { GMB } 150 \mathrm{mg} \\
\text { PBO }\end{array}$ & $\begin{array}{l}\text { GMB } 300 \mathrm{mg} \\
\text { GMB } 120 \mathrm{mg} \\
\text { GMB } 50 \mathrm{mg} \\
\text { GMB } 5 \mathrm{mg} \\
\text { PBO }\end{array}$ & $\begin{array}{l}\text { GMB } 120 \mathrm{mg} \\
\text { GMB } 240 \mathrm{mg}\end{array}$ \\
\hline Treatment regimen & $\begin{array}{l}\text { Subcutaneous injection every } 2 \\
\text { weeks }\end{array}$ & $\begin{array}{l}\text { Subcutaneous injection every } 28 \\
\text { days }\end{array}$ & Subcutaneous injection every month \\
\hline
\end{tabular}

Abbreviations: GMB galcanezumab, ITT intent-to-treat, NCT national clinical trial, $P B O$ placebo

${ }^{a}$ At least eight of the monthly headache days were migraine headache days

${ }^{b}$ Permitted migraine preventive medications included topiramate and propranolol

patients from EVOLVE-1, EVOLVE-2, REGAIN, the open-label extension of REGAIN, a phase 2 placebocontrolled trial (CGAB), and a phase 3 open-label trial (CGAJ). Safety outcomes were analyzed using two populations: 1) Phase 3_Pooled population, which included both galcanezumab- and placebo-treated patients, and 2) All GMB Exposure population, which included only galcanezumab-treated patients from all trials.

\section{Pharmacokinetic analyses}

A prior population PK analysis using PK data obtained from healthy adults and adult patients with migraine dosed with 5 to $300 \mathrm{mg}$ galcanezumab showed that the typical population estimate of $\mathrm{CL} / \mathrm{F}$ was $0.00785 \mathrm{~L} / \mathrm{h}$ with $34 \%$ inter-individual variability (IIV), and the typical population estimate of V/F was $7.33 \mathrm{~L}$ with $34 \%$ IIV [20]. In the current study, age was examined as a potential 
Table 2 Clinical trial populations included in analyses

\begin{tabular}{|c|c|c|c|c|c|c|}
\hline \multirow[t]{2}{*}{ Analysis } & \multicolumn{6}{|l|}{ Clinical Trials } \\
\hline & $\begin{array}{l}\text { EVOLVE-1 } \\
\text { Phase } 3 \text { DB }\end{array}$ & $\begin{array}{l}\text { EVOLVE-2 } \\
\text { Phase } 3 \text { DB }\end{array}$ & $\begin{array}{l}\text { REGAIN } \\
\text { Phase } 3 \\
\text { DB and OL }\end{array}$ & $\begin{array}{l}\text { ART-01 } \\
\text { Phase } 2 \text { DB }\end{array}$ & $\begin{array}{l}\text { CGAB } \\
\text { Phase 2DB }\end{array}$ & $\begin{array}{l}\text { CGAJ } \\
\text { Phase } 3 \text { OL }\end{array}$ \\
\hline Pharmacokinetic $^{a}$ & $x$ & $x$ & $x$ & & $x$ & $x$ \\
\hline Baseline comparison & $x$ & $x$ & $x$ & & & \\
\hline Efficacy outcomes & $x$ & $x$ & $x^{b}$ & & & \\
\hline \multicolumn{7}{|l|}{ Safety outcomes } \\
\hline Phase 3_Pooled & $x$ & $x$ & $x^{b}$ & & & \\
\hline All GMB Exposure & $x$ & $x$ & $X$ & $x$ & $X$ & $x$ \\
\hline
\end{tabular}

Abbreviations: All GMB Exposure Patients treated with any GMB dose in any duration, DB Double blind, GMB Galcanezumab, OL Open label, Phase 3_Pooled, all patients from the 3 placebo-controlled phase 3 trials

ancludes results from phase 2 and 3 studies with 28-day or monthly dosing regimens

${ }^{b}$ Includes results from DB phase of trials only

continuous covariate on $\mathrm{CL} / \mathrm{F}$ and $\mathrm{V} / \mathrm{F}$ of galcanezumab using a covariate power model (Eq. 1), exponential model (Eq. 2), and linear model (Eq. 3) as shown below:

$$
\begin{aligned}
& \mathrm{P}=\Theta 1 \times(\mathrm{COV} / \mathrm{MED})^{\Theta 2} \\
& \mathrm{P}=\Theta 1 \times \mathrm{e}^{\Theta 2[\mathrm{COV}-\mathrm{MED}]} \\
& \mathrm{P}=\Theta 1(1+\Theta 2[\mathrm{COV}-\mathrm{MED}])
\end{aligned}
$$

where $\mathrm{P}$ is the estimate of $\mathrm{CL} / \mathrm{F}$ or $\mathrm{V} / \mathrm{F}$ for an individual patient, $\Theta 1$ represents the typical value of $\mathrm{CL} / \mathrm{F}$ or $\mathrm{V} / \mathrm{F}$ in the patient population, $\Theta 2$ represents the effect of age, COV is the patient age, and MED is the population median age. Details of the covariate analyses can be found elsewhere [20]. Briefly, the effect of age was considered to be statistically significant if the value of the model objective function (MOF) after testing age as a covariate was reduced by 6.635 points $(p$-value $<0.01)$ and there was a $>5 \%$ decrease in the IIV of $\mathrm{CL} / \mathrm{F}$ or $\mathrm{V} / \mathrm{F}$ compared to the typical base model IIV values of $40 \%$ for $\mathrm{CL} / \mathrm{F}$ and $34 \%$ for $\mathrm{V} / \mathrm{F}$.

\section{Analyses of baseline characteristics and efficacy outcomes Clinical trials and age groupings}

Efficacy outcomes and corresponding baseline frequencies were analyzed for the patient populations in the double-blind sections of the three phase 3, placebocontrolled trials. Patients from EVOLVE-1 and EVOLVE-2 trials were pooled to make a single population of patients with episodic migraine and were analyzed separately from the population of patients with chronic migraine (REGAIN). Both patient groups were divided into 4 age groups, $\leq 40,>40$ to $\leq 50,>50$ to $\leq 55$, and $>55$ to $\leq 65$ years. Patients older than 50 years were divided into age groups of $>50$ to $\leq 55$ years and $>55$ to $\leq 65$ years in order to have the two groups include comparable numbers of patients.

\section{Baseline characteristics}

Baseline levels for monthly migraine headache days and monthly migraine headache days with acute medication use were determined during the prospective baseline period lasting 30-40 days before the start of the doubleblind treatment phase. Baseline health outcome measures including Migraine-Specific Quality-of-life Questionnaire v2.1 (MSQ), and Migraine Disability Assessment (MIDAS) scores were also collected to cover the baseline period. The MSQ measures a person's level of functioning, with a higher score indicating better function. The MIDAS assesses the level of headache-related disability due to migraine, with a higher score indicating more disability [21]. Trial participants also reported patient global impression of severity (PGI-S), a measure that had the patient answer the question "Considering migraine as a chronic condition, how would you rate your level of illness?", on a scale of 1 ("normal, not at all ill") to 7 ("extremely ill").

\section{Statistical analyses for baseline characteristics}

For all baseline patient and migraine characteristics, the overall means of each age group were compared using an analysis of variance model, with terms for age group and study for the episodic trials and only age group for the chronic trial.

\section{Efficacy outcomes}

Efficacy outcomes evaluated in this analysis by age were the overall mean changes from baseline in monthly migraine headache days and monthly migraine headache days with acute medication use. Percentage of patients experiencing $\geq 50 \%$ and $\geq 75 \%$ reductions from baseline in monthly migraine headache days were also calculated using the average over all months in the trials.

\section{Statistical analyses for efficacy outcomes}

The overall mean change from baseline in the number of migraine headache days and migraine headache days 
with acute medication use per month by age group were analyzed using mixed model for repeated measures approach both for age subgroup-by-treatment interaction and treatment comparisons within each age group. To analyze $\geq 50 \%$ and $\geq 75 \%$ response rates by age group, generalized linear mixed model was used both for age subgroup-by-treatment interaction and treatment comparisons within each age group.

\section{Analyses for safety outcomes Safety datasets and age groupings}

Safety outcomes were examined for two sets of patients, the "double-blind treatment phase" dataset (Phase 3 Pooled) and the "all galcanezumab exposure" dataset (All GMB Exposure), defined in Table 2. Patients were divided into 4 age groups using the median age of 42 years as the upper limit for the youngest age group, resulting in the patient subgroups of $<42,42$ to $<50,50$ to $<60$, and 60 to $\leq 65$ years of age. These groups were slightly different than those used in the efficacy analyses, with the most important difference being in the age range for the oldest group (60 to $\leq 65$ years instead of > 55 to $\leq 65$ years), which allowed for a more specific analysis of the safety of galcanezumab in the oldest patients in the trials.

\section{Safety outcomes}

Safety outcomes evaluated in this subgroup analysis included number of treatment-emergent adverse events (TEAEs), serious adverse events (SAEs), and discontinuations due to adverse events (DCAEs). TEAEs were defined as adverse events that occurred for the first time or worsened in severity after the baseline period. Specific TEAEs that were likely to be cardiovascular in nature were evaluated using the standardized Medical Dictionary for Regulatory Activities (MedDRA version 19.1) queries (SMQs), including only narrow terms, for hypertension, embolic and thrombotic events, and ischemic heart disease. Occurrences of high systolic and diastolic BP were determined for each age group. An increased (high) BP postbaseline was defined as $\geq 140 \mathrm{mmHg}$ for systolic $\mathrm{BP}$ and $\geq 90 \mathrm{mmHg}$ for diastolic $\mathrm{BP}$ measured at any time after the baseline period, with a concomitant increase of $\geq 20 \mathrm{mmHg}$ (systolic BP) and $\geq 10 \mathrm{mmHg}$ (diastolic BP), from the baseline BP.

\section{Statistical analyses performed for safety outcomes}

Exposure-adjusted incidence rates (EAIRs) and unadjusted percentages are presented for all safety outcomes for both the "Phase 3_Pooled" and "All GMB Exposure" populations. An EAIR is calculated as 100 times the number of patients experiencing the specific event, divided by the event-specific total patient-year-atrisk. Patient-year-at-risk accrues up to the date of the first occurrence of the event for patients with the event, and to the end of the specified study period for patients without the event.

For the Phase 3_Pooled population, exposureadjusted analyses of safety outcomes within an age subgroup used a Poisson regression model with explanatory variables of study and treatment and an offset term of time-at-risk. $P$-values comparing galcanezumab and placebo treatment groups were determined using a likelihood ratio test of the treatment effect. Treatment-by-age group interaction for safety outcomes was evaluated using a Poisson regression model with explanatory variables of study, treatment, age group, and treatment-by-age group interaction, with the offset term of time-at-risk.

For the All GMB Exposure population, only galcanezumab-treated patients were combined for analysis; no $p$-values are presented since there were no treatment comparisons.

\section{Results}

\section{Pharmacokinetics}

Covariate analysis revealed that age had a statistically significant effect on CL/F using the power model $(p<$ 0.01 , reduction in MOF of 13) and the exponential model $(p<0.01$, reduction in MOF of 20$)$, but not the linear model $(p>0.01$, increase in MOF of 21). However, the IIV for CL/F was unchanged from $40 \%$ when age was included in the population PK model. Since the prespecified criteria for age as a covariate on galcanezumab $\mathrm{CL} / \mathrm{F}$ was a decrease of 6.635 points $(p$-value $<0.01)$ in the MOF and a decrease in the IIV of the parameter by $>5 \%$, the criteria overall were not met. The relationship between age and CL/F is illustrated in Fig. 1a, demonstrating a minimal change across patients who were between 18 and 65 years of age. The CL/F was $0.00842 \mathrm{~L} / \mathrm{h}$ at 18 years and $0.00739 \mathrm{~L} / \mathrm{h}$ at 65 years based on the exponential model, resulting in a minimal decrease of $14 \%$ in $\mathrm{CL} / \mathrm{F}$ from the youngest to the oldest patients evaluated. Overall, age was not considered a clinically meaningful covariate on galcanezumab $\mathrm{CL} / \mathrm{F}$.

For V/F, age did not have a statistically significant effect using the power model $(p>0.01$, reduction in MOF of $18)$, exponential model $(p>0.01$, increase in MOF of 11$)$, or linear model $(p>0.01$, reduction in MOF of 1.4). Therefore, age was not considered to be a meaningful covariate on galcanezumab V/F. For completeness, the relationship between age and V/F is illustrated in Fig. 1b across patients who were between 18 and 65 years of age.

\section{Baseline measurements Migraine characteristics}

A total of 2886 patients were enrolled in the three placebo-controlled, double-blind phase 3 trials included 
a.

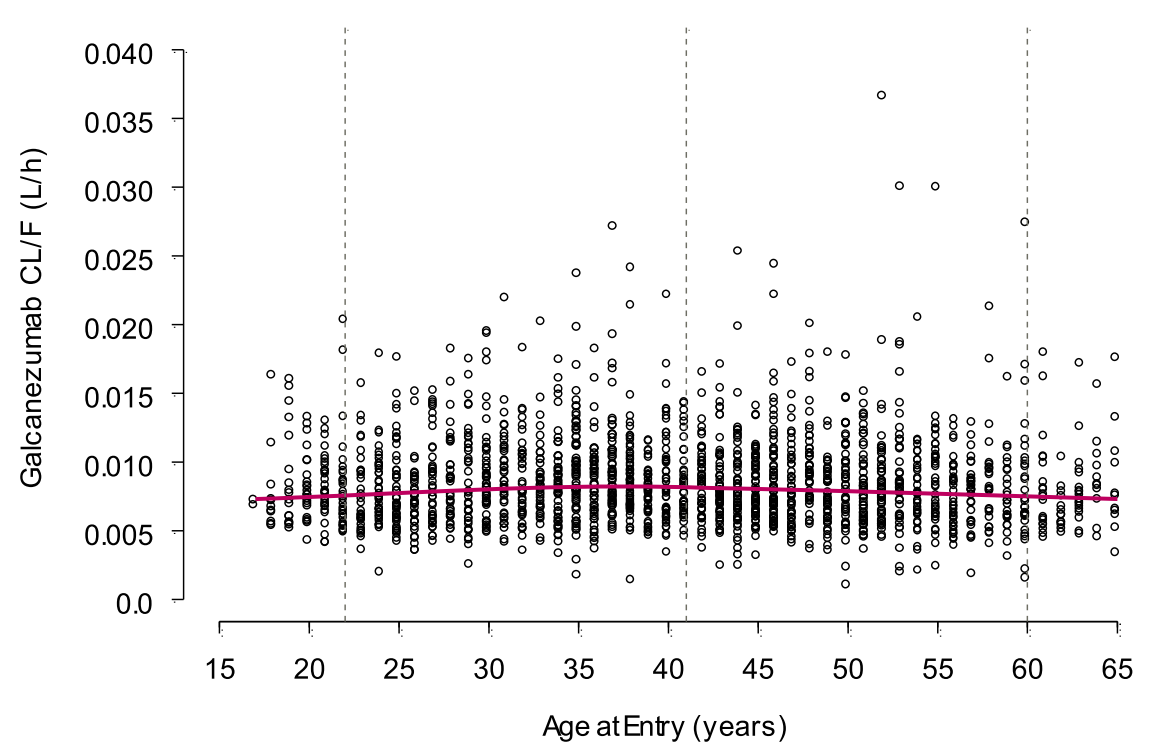

b.

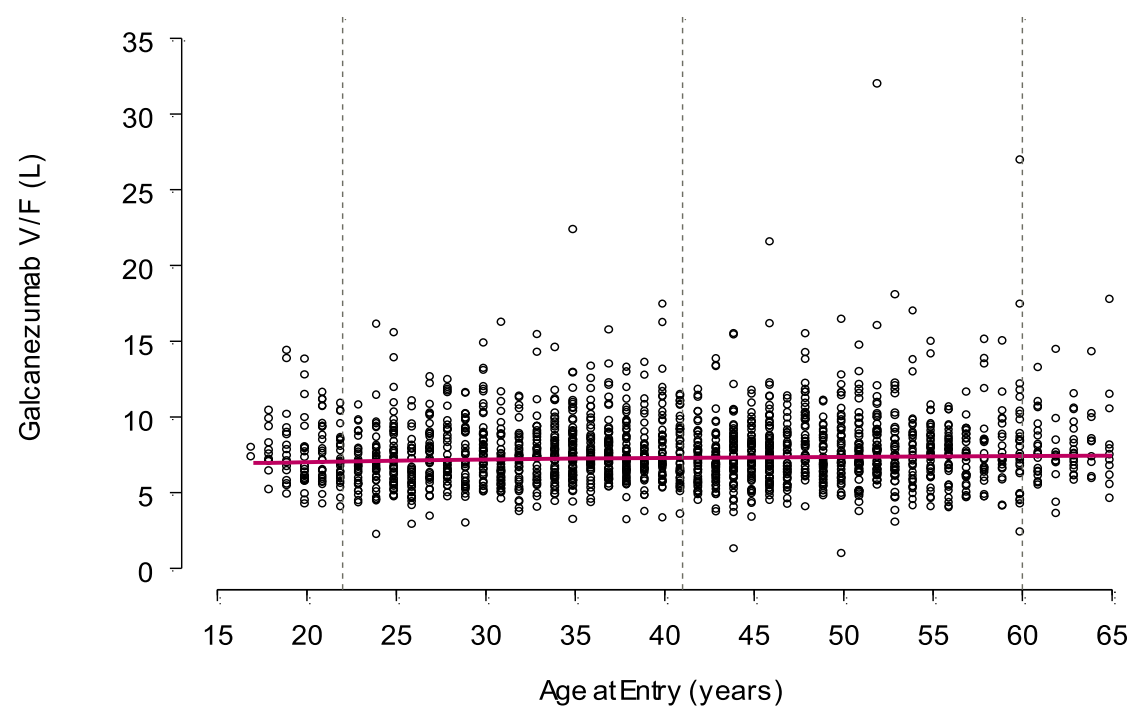

Fig. 1 Effect of age (18-65 years) on galcanezumab CL/F and V/F

in the efficacy analysis. There were 1344 patients (47\%) who were aged $\leq 40$ years, 849 patients $(29 \%)$ between the ages of $>40$ and $\leq 50,336$ patients (12\%) between the ages of $>50$ and $\leq 55$, and 357 patients (12\%) between the ages of $>55$ and $\leq 65$.

The baseline migraine characteristics of patients in the 4 age groups used to analyze efficacy outcomes are shown in Table 3. As expected, the number of years since diagnosis increased with increasing age for patients with episodic and chronic migraine. The numbers of monthly migraine headache days were similar for all age groups. Statistical comparison of the 4 age groups showed no significant difference between age subgroups for overall mean monthly migraine headache days in the episodic studies. However, in chronic migraine trials, the comparison of overall means between age groups showed some significant differences between the groups, though there did not appear to be a consistent trend of increasing or decreasing with age. There were also statistically significant differences among age groups for mean monthly migraine headache days with acute medication use, for both episodic and chronic migraine trials. While there was no discernable trend in patients with episodic migraine, patients with chronic migraine in age groups $>40$ years old generally had higher means for monthly migraine headache days with acute medication use.

\section{Patient evaluations of migraine effects}

The baseline scores for measures of function and disability, as well as disease severity, for patients in the 
Table 3 Baseline migraine characteristics and patient function and disability for 4 age groups (efficacy groupings)

\begin{tabular}{|c|c|c|c|c|c|c|c|c|c|}
\hline & & \multicolumn{4}{|c|}{ Migraine Characteristics } & \multicolumn{4}{|c|}{ Patient Function and Disability } \\
\hline & & & $\begin{array}{l}\text { Years since } \\
\text { diagnosis }\end{array}$ & $\begin{array}{l}\text { Monthly migraine } \\
\text { headache days }\end{array}$ & $\begin{array}{l}\text { Monthly migraine headache days with } \\
\text { acute medication }\end{array}$ & & $\begin{array}{l}\text { MSQ-RFR } \\
\text { score }\end{array}$ & $\begin{array}{l}\text { PGI-S } \\
\text { score }\end{array}$ & $\begin{array}{l}\text { MIDAS total } \\
\text { score }\end{array}$ \\
\hline $\begin{array}{l}\text { Age group } \\
\text { (years) }\end{array}$ & Treat. & $\mathrm{N}$ & Mean (SD) & Mean (SD) & Mean (SD) & $\mathrm{N}$ & $\begin{array}{l}\text { Mean } \\
\text { (SD) }\end{array}$ & $\begin{array}{l}\text { Mean } \\
\text { (SD) }\end{array}$ & Mean (SD) \\
\hline \multicolumn{10}{|l|}{ Episodic } \\
\hline$\leq 40$ & $\begin{array}{l}\text { PBO } \\
120 \\
240\end{array}$ & $\begin{array}{l}381 \\
219 \\
220\end{array}$ & $\begin{array}{l}14.0(7.6) \\
14.2(8.5) \\
14.3(7.7)\end{array}$ & $\begin{array}{l}9.3(2.9) \\
9.3(3.0) \\
9.2(2.9)\end{array}$ & $\begin{array}{l}6.9(3.5) \\
7.1(3.6) \\
7.1(3.4)\end{array}$ & $\begin{array}{l}379 \\
219 \\
218\end{array}$ & $\begin{array}{l}52.1(15.9) \\
51.8(15.4) \\
48.9 \\
(17.1)^{2}\end{array}$ & $\begin{array}{l}4.2 \\
(1.1)^{1} \\
4.2(1.1) \\
4.3(1.2)\end{array}$ & $\begin{array}{l}33.1(26.4) \\
29.9(23.5) \\
37.9(28.1)^{2}\end{array}$ \\
\hline$>40$ to $\leq 50$ & $\begin{array}{l}\text { PBO } \\
120 \\
240\end{array}$ & $\begin{array}{l}298 \\
125 \\
113\end{array}$ & $\begin{array}{l}22.0(11.5) \\
23.1(10.4) \\
22.4(11.8)\end{array}$ & $\begin{array}{l}9.3(3.1) \\
8.9(2.7) \\
9.0(2.9)\end{array}$ & $\begin{array}{l}8.2(3.3) \\
7.7(3.1) \\
7.8(3.0)\end{array}$ & $\begin{array}{l}296 \\
124 \\
111\end{array}$ & $\begin{array}{l}51.6(14.4) \\
51.6(15.7) \\
51.5(15.7)\end{array}$ & $\begin{array}{l}4.3(1.2) \\
4.4(1.1) \\
4.4(1.2)\end{array}$ & $\begin{array}{l}34.0(31.4) \\
35.6(31.0) \\
30.4(24.6)\end{array}$ \\
\hline$>50$ to $\leq 55$ & $\begin{array}{l}\text { PBO } \\
120 \\
240\end{array}$ & $\begin{array}{l}96 \\
54 \\
58\end{array}$ & $\begin{array}{l}25.3(12.8) \\
27.8(12.2) \\
26.4(13.1)\end{array}$ & $\begin{array}{l}8.7(3.0) \\
9.1(2.9) \\
9.1(3.2)\end{array}$ & $\begin{array}{l}7.7(3.5) \\
8.1(3.3) \\
8.0(3.3)\end{array}$ & $\begin{array}{l}96 \\
54 \\
58\end{array}$ & $\begin{array}{l}51.7(17.1) \\
50.8(16.3) \\
50.3(17.3)\end{array}$ & $\begin{array}{l}4.3(1.3) \\
4.2(1.4) \\
4.4(1.2)\end{array}$ & $\begin{array}{l}32.0(23.1) \\
36.3(38.7) \\
31.8(33.7)\end{array}$ \\
\hline$>55$ to $\leq 65$ & $\begin{array}{l}\text { PBO } \\
120 \\
240\end{array}$ & $\begin{array}{l}119 \\
46 \\
44\end{array}$ & $\begin{array}{l}34.1(14.0) \\
34.8(13.9) \\
30.5(14.6)\end{array}$ & $\begin{array}{l}8.7(3.0) \\
8.9(3.4) \\
8.8(3.0)\end{array}$ & $\begin{array}{l}7.7(3.2) \\
7.5(3.9) \\
7.3(3.3)\end{array}$ & $\begin{array}{l}116 \\
46 \\
43\end{array}$ & $\begin{array}{l}54.0(16.3) \\
55.3(13.8) \\
54.2(15.2)\end{array}$ & $\begin{array}{l}4.2(1.2) \\
4.0(1.1) \\
4.3(1.1)\end{array}$ & $\begin{array}{l}31.7(36.6) \\
26.0(23.3) \\
30.3(29.2)\end{array}$ \\
\hline$p$-value ${ }^{3}$ & & & $<0.001$ & 0.128 & $<0.001$ & & 0.075 & 0.349 & 0.468 \\
\hline \multicolumn{10}{|l|}{ Chronic } \\
\hline$\leq 40$ & $\begin{array}{l}\text { PBO } \\
120 \\
240\end{array}$ & $\begin{array}{l}253 \\
144 \\
127\end{array}$ & $\begin{array}{l}14.8(8.2) \\
14.7(8.8) \\
13.3(8.2)\end{array}$ & $\begin{array}{l}20.0(4.6) \\
19.7(4.2) \\
19.6(4.6)\end{array}$ & $\begin{array}{l}14.3(7.1) \\
13.9(6.5) \\
13.3(6.2)\end{array}$ & $\begin{array}{l}247 \\
141 \\
125\end{array}$ & $\begin{array}{l}37.8(16.7) \\
37.6(17.0) \\
39.1(17.1)\end{array}$ & $\begin{array}{l}4.8(1.3) \\
4.9(1.2) \\
4.7(1.2)\end{array}$ & $\begin{array}{l}69.1(53.6) \\
64.2(51.7) \\
76.4(66.6)\end{array}$ \\
\hline$>40$ to $\leq 50$ & $\begin{array}{l}\text { PBO } \\
120 \\
240\end{array}$ & $\begin{array}{l}162 \\
75 \\
76\end{array}$ & $\begin{array}{l}24.1(11.3) \\
23.6(11.9) \\
21.9(12.1)\end{array}$ & $\begin{array}{l}19.4(4.5) \\
19.1(4.3) \\
19.1(4.6)\end{array}$ & $\begin{array}{l}16.7(5.7) \\
16.0(5.8) \\
15.2(6.3)\end{array}$ & $\begin{array}{l}159 \\
75 \\
74\end{array}$ & $\begin{array}{l}37.7(18.3) \\
41.0(18.1) \\
37.5(18.3)\end{array}$ & $\begin{array}{l}5.1(1.2) \\
4.8(1.3) \\
5.0(1.5)\end{array}$ & $\begin{array}{l}76.3(67.7) \\
59.3(45.9)^{2} \\
65.4(60.8)\end{array}$ \\
\hline$>50$ to $\leq 55$ & $\begin{array}{l}\text { PBO } \\
120 \\
240\end{array}$ & $\begin{array}{l}65 \\
31 \\
32\end{array}$ & $\begin{array}{l}28.7(13.5) \\
25.8(14.5) \\
24.1(11.9)\end{array}$ & $\begin{array}{l}18.9(3.9) \\
18.3(4.7) \\
17.4(4.3)\end{array}$ & $\begin{array}{l}15.8(5.6) \\
16.0(6.7) \\
13.4(5.6)\end{array}$ & $\begin{array}{l}63 \\
29 \\
32\end{array}$ & $\begin{array}{l}38.6(16.7) \\
40.9(17.8) \\
38.7(13.9)\end{array}$ & $\begin{array}{l}4.9(1.2) \\
4.6(1.2) \\
4.9(1.2)\end{array}$ & $\begin{array}{l}63.0(49.5) \\
63.3(51.1) \\
60.5(48.9)\end{array}$ \\
\hline$>55$ to $\leq 65$ & $\begin{array}{l}\text { PBO } \\
120 \\
240\end{array}$ & $\begin{array}{l}78 \\
28 \\
42\end{array}$ & $\begin{array}{l}35.0(12.9) \\
34.9(13.6) \\
34.3(11.7)\end{array}$ & $\begin{array}{l}19.0(5.2) \\
19.4(4.4) \\
19.4(4.6)\end{array}$ & $\begin{array}{l}16.8(6.5) \\
18.1(4.0) \\
17.6(5.7)\end{array}$ & $\begin{array}{l}77 \\
27 \\
41\end{array}$ & $\begin{array}{l}41.5(16.7) \\
41.6(16.4) \\
41.2(18.9)\end{array}$ & $\begin{array}{l}4.8(1.3) \\
4.6(1.5) \\
5.2(1.4)\end{array}$ & $\begin{array}{l}56.0(49.7) \\
61.4(47.5) \\
60.8(71.8)\end{array}$ \\
\hline$p$-value ${ }^{3}$ & & & $<0.001$ & 0.006 & $<0.001$ & & 0.214 & 0.181 & 0.128 \\
\hline
\end{tabular}

Abbreviations: 120 Galcanezumab 120 mg, 240 Galcanezumab 240 mg, MIDAS Migraine Disability Assessment, MSQ-RFR Migraine-specific quality-of-life questionnaire role function-restrictive domain, PBO Placebo, PGI-S Patient global impression of severity, SD Standard deviation, Treat Treatment

${ }^{1}$ Group included 380 patients

${ }^{2} p$-value $<0.05$ compared to PBO-treatment arm in same age group

${ }^{3} p$-value compares overall means between age groups

4 age groups used to analyze efficacy outcomes are shown in Table 3. Baseline scores were similar across age groups for MSQ role function restrictive domain, PGI-S, and MIDAS, in both episodic and chronic migraine trials (all interaction $p$-values $>0.05$ ), though there were three instances where a galcanezumab treatment group had a baseline score that was statistically different from the mean score of the placebo group within an age group.

\section{Efficacy results}

Changes in number of monthly migraine headache days and monthly migraine headache days with acute medication use

Overall mean changes from baseline in monthly migraine headache days and monthly migraine headache days with acute medication use in patients with episodic and chronic migraine are shown in Fig. 2. In patients with episodic migraine, galcanezumab treatment resulted in significantly greater reduction in monthly migraine headache days and monthly migraine headache days with acute medication use for all age groups $(p<0.001)$.

Age did not appear to affect changes in monthly migraine headache days for galcanezumab- versus placebotreated patients, as treatment-by-subgroup interactions were not statistically significant for patients with either episodic or chronic migraine (interaction $p$-values $>0.05$ ).

However, there was a significant treatment-bysubgroup interaction for change from baseline in monthly migraine headache days with acute medication use in patients with episodic migraine treated with galcanezumab $240 \mathrm{mg}$ versus placebo, where it appeared that older patients treated with galcanezumab $240 \mathrm{mg}$ had 


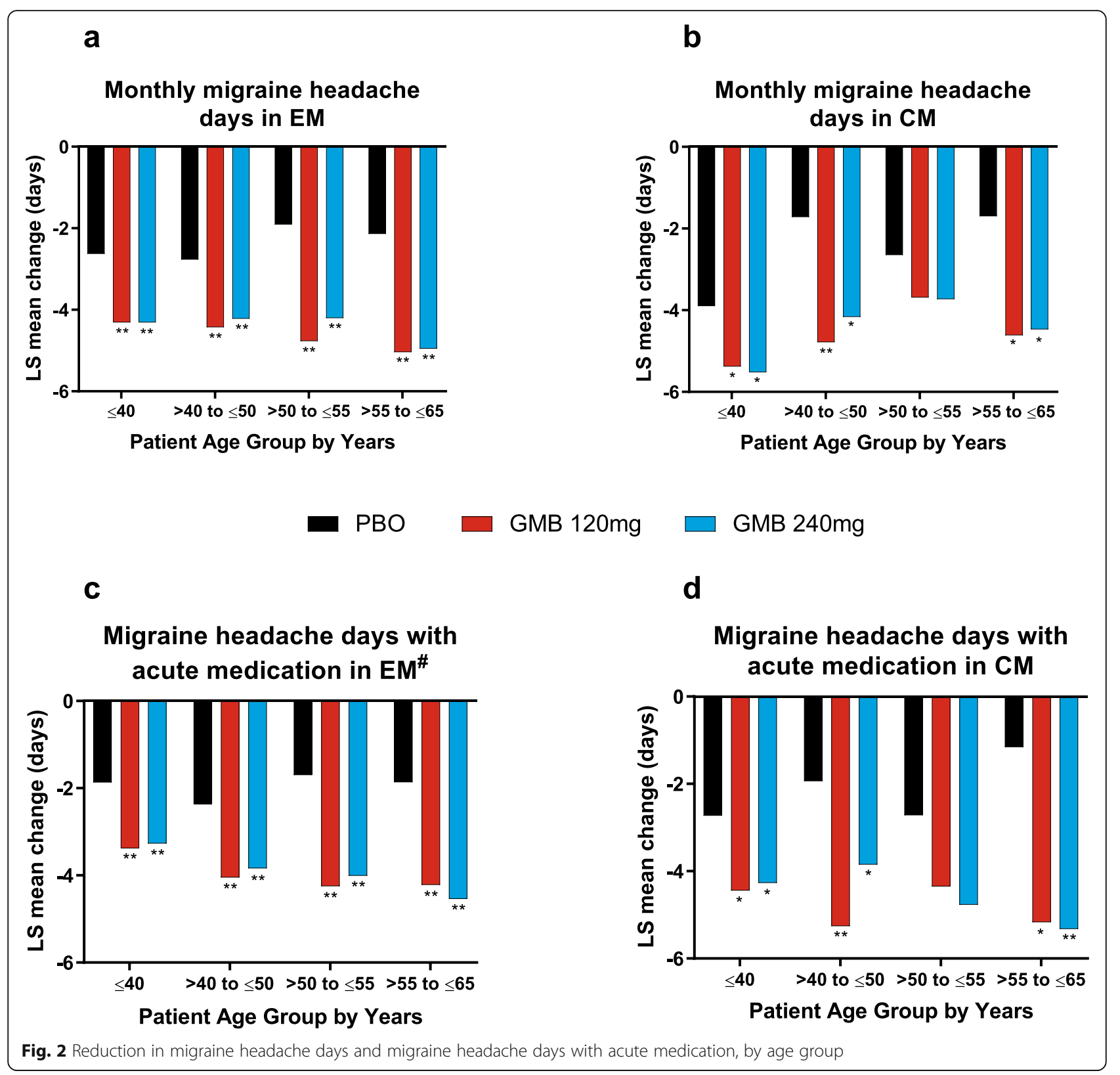

larger reductions than younger patients (interaction $p$ value $=0.024)$.

\section{$\geq 50 \%$ and $\geq 75 \%$ improvement in monthly migraine headache days}

The percentages of patients experiencing $\geq 50 \%$ and $\geq 75 \%$ reductions from baseline in monthly migraine headache days are shown in Fig. 3. In patients with episodic migraine, people treated with galcanezumab experienced $\geq 50 \%$ and $\geq 75 \%$ reductions in monthly migraine headache days at significantly higher rates than people treated with placebo, for all age groups. Patients with chronic migraine also experienced $\geq 50 \%$ and $\geq 75 \%$ reductions at higher percentages when treated with galcanezumab compared with placebo, but the differences were statistically significant only for some age groups.

Age did not affect the likelihood of a patient achieving these reductions in monthly migraine headache days for galcanezumab- versus placebo-treated patients, as treatment-by-subgroup interactions were not significant in episodic and chronic studies (interaction $p$-values > 0.05 , or not calculable for $\geq 75 \%$ reduction in patients with chronic migraine due to insufficient number of patients).

Safety results

Safety population

In the Phase 3_Pooled group, there were 1429 patients (50\%) who were aged < 42 years, 681 patients $(24 \%)$ 


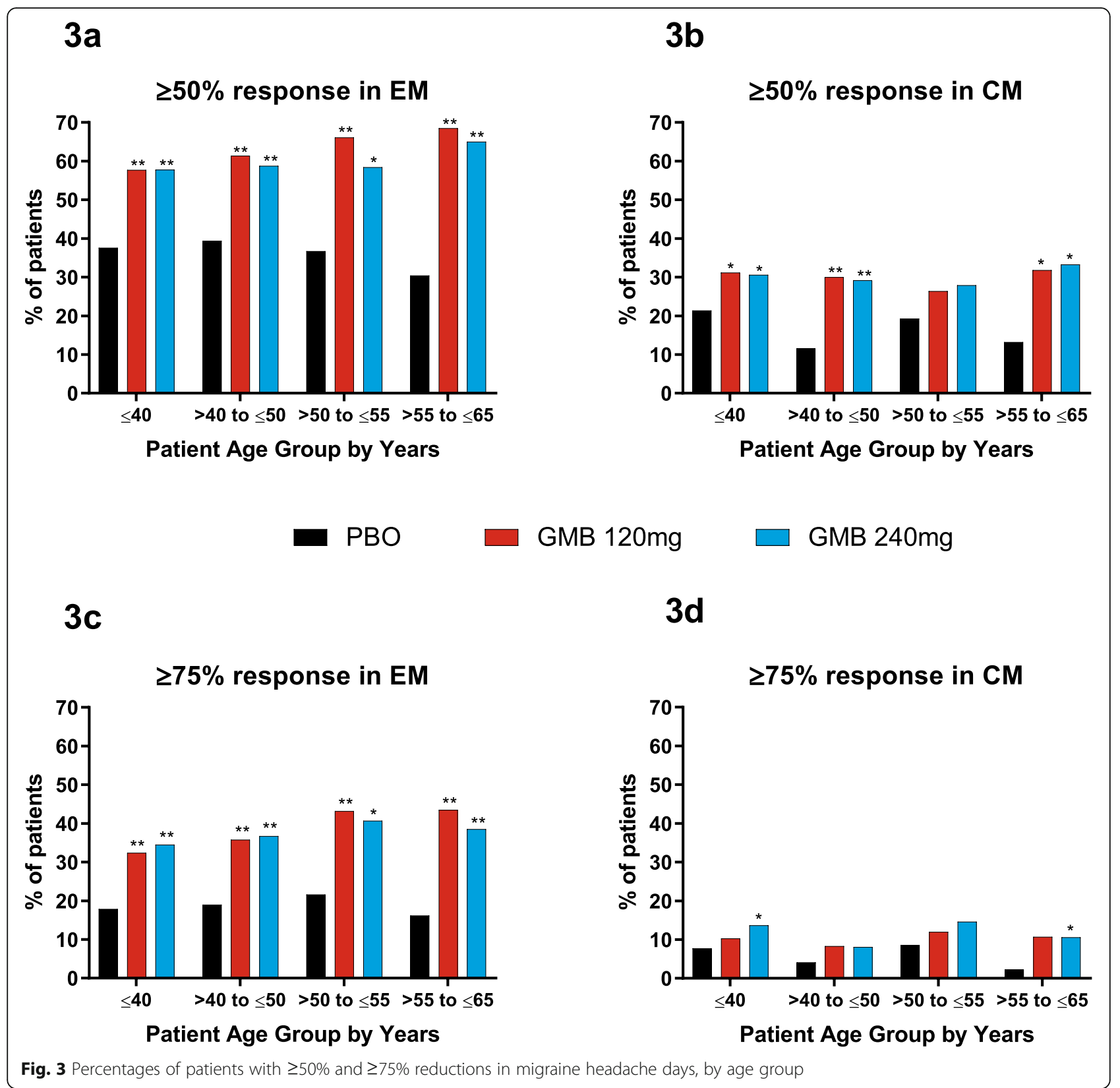

between the ages of 42 and $<50$ years, 609 patients (21\%) between the ages of 50 and $<60$ years, and 167 patients $(6 \%)$ between the ages of 60 and $\leq 65$ years, who were evenly divided between galcanezumab and placebo treatment. Safety analyses were also conducted using the All GMB Exposure population, which included a total of 2586 galcanezumab-treated patients from the Phase 3 Pooled group, as well as from CGAB, Art-01, and CGAJ clinical trials, and also included data from the open-label phase of Study CGAI. In the All GMB Exposure group, there were 1295 patients (50\%) who were aged <42 years, 599 patients (23\%) between the ages of 42 and < 50 years, 538 patients (21\%) between the ages of 50 and $<60$ years, and 154 patients $(6 \%)$ between the ages of 60 and $\leq 65$ years.

TEAEs, SAEs, and DCAEs

In the double-blind treatment phase, TEAEs were reported less frequently by patients $\geq 60$ years old treated with galcanezumab versus placebo, as indicated by a lower incidence rate (EAIR) (Table 4). The incidence rate for galcanezumab-treated patients $\geq 60$ years old was also numerically lower than rates seen in younger galcanezumab-treated age groups. No treatment-by-age subgroup interactions were observed for TEAEs $(p=0.097)$ or SAEs $(p=0.107)$ in the double-blind 
Table 4 Incidence rates for TEAEs, SAEs, and DCAEs

\begin{tabular}{|c|c|c|c|c|c|c|c|c|}
\hline \multirow[b]{2}{*}{ Dose Group } & \multirow[b]{2}{*}{ Age Group (years) } & \multirow[b]{2}{*}{$\mathrm{N}$} & \multicolumn{2}{|c|}{ Patients with One or More TEAE } & \multicolumn{2}{|c|}{ Patients with One or More SAE } & \multicolumn{2}{|c|}{ Patients with DCAE } \\
\hline & & & $\mathrm{n} / \mathrm{TPY}$ & EAIR $(95 \% \mathrm{Cl})$ & $\mathrm{n} / \mathrm{TPY}$ & EAIR $(95 \% \mathrm{Cl})$ & $\mathrm{n} / \mathrm{TPY}$ & EAIR $(95 \% \mathrm{Cl})$ \\
\hline \multicolumn{9}{|c|}{ Double-blind treatment phase } \\
\hline $\begin{array}{l}\text { Phase 3_Pooled } \\
\text { Placebo }\end{array}$ & $\begin{array}{l}<42 \\
42 \text { to }<50 \\
50 \text { to }<60 \\
60 \text { to } \leq 65\end{array}$ & $\begin{array}{l}687 \\
359 \\
309 \\
96\end{array}$ & $\begin{array}{l}397 / 134.7 \\
197 / 78.1 \\
177 / 64.3 \\
56 / 18.1\end{array}$ & $\begin{array}{l}294.8(266.5,325.2) \\
252.3(218.3,290.0) \\
275.2(236.1,318.8) \\
308.7(233.2,400.9)\end{array}$ & $\begin{array}{l}8 / 248.1 \\
0 / 136.2 \\
2 / 112.8 \\
4 / 33.3\end{array}$ & $\begin{array}{l}3.2(1.4,6.4) \\
0.0(\mathrm{NA}, 2.7) \\
1.8(0.2,6.4) \\
12.0(3.3,30.7)\end{array}$ & $\begin{array}{l}11 / 248.2 \\
1 / 136.1 \\
6 / 112.5 \\
6 / 33.2\end{array}$ & $\begin{array}{l}4.4(2.2,7.9) \\
0.7(0.0,4.1) \\
5.3(2.0,11.6) \\
18.1(6.6,39.3)\end{array}$ \\
\hline $\begin{array}{l}\text { Phase 3_Pooled } \\
\text { GMB }\end{array}$ & $\begin{array}{l}<42 \\
42 \text { to }<50 \\
50 \text { to }<60 \\
60 \text { to } \leq 65\end{array}$ & $\begin{array}{l}742 \\
322 \\
300 \\
71\end{array}$ & $\begin{array}{l}472 / 143.2 \\
202 / 64.9 \\
198 / 54.9 \\
41 / 15.8\end{array}$ & $\begin{array}{l}329.6(300.5,360.7) \\
311.4(269.9,357.4)^{1} \\
360.5(312.0,414.3)^{1} \\
259.9(186.5,352.5)\end{array}$ & $\begin{array}{l}10 / 272.1 \\
2 / 122.7 \\
9 / 110.8 \\
2 / 25.9\end{array}$ & $\begin{array}{l}3.7(1.8,6.8) \\
1.6(0.2,5.9) \\
8.1(3.7,15.4) \\
7.7(0.9,27.9)\end{array}$ & $\begin{array}{l}22 / 272.3 \\
7 / 122.2 \\
5 / 112.2 \\
1 / 26.4\end{array}$ & $\begin{array}{l}8.1(5.1,12.2) \\
5.7(2.3,11.8) \\
4.5(1.5,10.4) \\
3.8(0.1,21.1)\end{array}$ \\
\hline \multicolumn{4}{|c|}{ Treatment-by-age group interaction $p$-value } & 0.097 & & 0.107 & & 0.022 \\
\hline \multicolumn{9}{|l|}{ All GMB exposure } \\
\hline All GMB Exposure & $\begin{array}{l}<42 \\
42 \text { to }<50 \\
50 \text { to }<60 \\
60 \text { to } \leq 65\end{array}$ & $\begin{array}{l}1295 \\
599 \\
538 \\
154\end{array}$ & $\begin{array}{l}913 / 308.3 \\
409 / 165.2 \\
381 / 130.3 \\
110 / 42.7\end{array}$ & $\begin{array}{l}296.2(277.3,316.0) \\
247.5(224.1,272.7) \\
292.5(263.8,323.4) \\
257.7(211.8,310.6)\end{array}$ & $\begin{array}{l}31 / 709.4 \\
12 / 358.1 \\
18 / 311.4 \\
5 / 89.0\end{array}$ & $\begin{array}{l}4.4(3.0,6.2) \\
3.4(1.7,5.9) \\
5.8(3.4,9.1) \\
5.6(1.8,13.1)\end{array}$ & $\begin{array}{l}51 / 714.3 \\
18 / 359.9 \\
18 / 313.8 \\
4 / 91.0\end{array}$ & $\begin{array}{l}7.1(5.3,9.4) \\
5.0(3.0,7.9) \\
5.7(3.4,9.1) \\
4.4(1.2,11.3)\end{array}$ \\
\hline
\end{tabular}

Abbreviations: All GMB Exposure, patients treated with any GMB dose in any duration, Cl Confidence interval, DCAE Discontinuation due to adverse event, EAIR Exposure-adjusted incidence rate, GMB Galcanezumab, Phase 3_Pooled all patients from the 3 placebo-controlled phase 3 trials, SAE Serious adverse event, TEAE Treatment-emergent adverse event, $T P Y$ Total patient years at risk

${ }^{1} p \leq 0.05$ compared with placebo

treatment phase population. There was a statistically significant treatment-by-age group interaction for DCAEs ( $p=0.022$ ), where placebo-treated patients $\geq 60$ years had a higher incidence rate than all other age subgroups, but there was no numerical increase in DCAEs in galcanezumab-treated patients of the same age. Overall, patients aged $\geq 60$ years who were treated with galcanezumab did not have increased incidences of TEAEs or DCAEs, and they were not more likely than patients in the 50 to $<60$ age group to experience an SAE.

Incidence rates for the All GMB Exposure population were consistent across age groups and comparable to the values for the double-blind treatment phase population for TEAEs, SAEs, and DCAEs.

\section{TEAEs likely to be cardiovascular in nature}

The incidence rates for a selection of TEAEs likely to be cardiovascular in nature are shown in Table 5. The most commonly reported cardiovascular-related TEAE in all age groups was hypertension. In both the Phase 3 Pooled and All GMB Exposure population sets, the hypertension incidence rates for galcanezumab-treated patients in the 60 to $\leq 65$ group were higher than the rates seen in the $<42$ age group and 42 to $<50$ age group. However, in the Phase 3_Pooled double-blind treatment phase population, which included a placebotreated group, the hypertension incidence rate for galcanezumab-treated patients in the 60 to $\leq 65$ age group was similar to that for the placebo-treated patients of the same age.

Very few patients reported embolic and thrombotic events or ischemic heart disease, and no galcanezumabtreated patients $\geq 60$ years old experienced either of these
TEAEs. In both the Phase 3_Pooled and All GMB Exposure population sets, no patient $\geq 60$ years treated with galcanezumab discontinued for a cardiovascular-related adverse event. Incidence rates for the All-GMB Exposure set were comparable to those of the double-blind treatment phase for hypertension, embolic and thrombotic events, and ischemic heart disease.

While there was some apparent increase in incidence rates for cardiovascular-related TEAEs with increasing age, there was no indication that galcanezumab treatment increased these rates. In the Phase 3_Pooled population, an analysis of all SMQs together showed no treatment-by-age group interaction $(p=0.449)$.

\section{High blood pressure}

The summary of incidence rates for high BP by age group is shown in Table 6 . In the double-blind treatment phase set, incidence rates for high systolic BP increased with increasing age in both placebo- and galcanezumab-treated groups, up to the $\geq 50$ to $<60$ age group, at which point the effect appeared to plateau. Incidence rates for high diastolic BP increased noticeably from the $<42$ age group to the 42 to $<50$ age group and remained higher in all older age groups. However, for both high systolic and high diastolic BP, galcanezumab treatment caused no significant increase in incidence rate compared to the placebo treatment of the same age group for all age groups. Incidence rates in the All-GMB Exposure set were comparable to or lower than rates observed in the double-blind treatment phase set.

Overall, there was no significant treatment-by-age group interaction for either systolic $(p=0.802)$ or 
Table 5 Treatment-emergent adverse events likely to be cardiovascular in nature

\begin{tabular}{|c|c|c|c|c|c|c|c|c|}
\hline \multirow[b]{2}{*}{ Dose Group } & \multirow[b]{2}{*}{ Age Group (years) } & \multirow[b]{2}{*}{ N } & \multicolumn{2}{|c|}{ 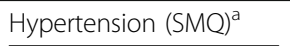 } & \multicolumn{2}{|c|}{ Embolic and Thrombotic events (SMQ) $^{a}$} & \multicolumn{2}{|c|}{ Ischemic heart disease $(S M Q)^{a}$} \\
\hline & & & $\mathrm{n} / \mathrm{TPY}$ & EAIR $(95 \% \mathrm{Cl})$ & $\mathrm{n} / \mathrm{TPY}$ & EAIR $(95 \% \mathrm{Cl})$ & $\mathrm{n} / \mathrm{TPY}$ & EAIR $(95 \% \mathrm{Cl})$ \\
\hline \multicolumn{9}{|c|}{ Double-blind treatment phase } \\
\hline $\begin{array}{l}\text { Phase 3_Pooled } \\
\text { Placebo }\end{array}$ & $\begin{array}{l}<42 \\
42 \text { to }<50 \\
50 \text { to }<60 \\
60 \text { to } \leq 65\end{array}$ & $\begin{array}{l}687 \\
359 \\
309 \\
96\end{array}$ & $\begin{array}{l}6 / 248.3 \\
7 / 134.9 \\
3 / 112.8 \\
2 / 33.5\end{array}$ & $\begin{array}{l}2.4(0.9,5.3) \\
5.2(2.1,10.7) \\
2.7(0.6,7.8) \\
6.0(0.7,21.6)\end{array}$ & $\begin{array}{l}1 / 249.2 \\
0 / 136.2 \\
1 / 113.2 \\
2 / 33.8\end{array}$ & $\begin{array}{l}0.4(0.0,2.2) \\
0.0(\mathrm{NA}, 2.7) \\
0.9(0.0,4.9) \\
5.9(0.7,21.4)\end{array}$ & $\begin{array}{l}0 / 249.3 \\
0 / 136.2 \\
0 / 113.3 \\
1 / 33.9\end{array}$ & $\begin{array}{l}0.0 \text { (NA, 1.5) } \\
0.0 \text { (NA, 2.7) } \\
0.0(\mathrm{NA}, 3.3) \\
3.0(0.1,16.4)\end{array}$ \\
\hline $\begin{array}{l}\text { Phase 3_Pooled } \\
\text { GMB }\end{array}$ & $\begin{array}{l}<42 \\
42 \text { to }<50 \\
50 \text { to }<60 \\
60 \text { to } \leq 65\end{array}$ & $\begin{array}{l}742 \\
322 \\
300 \\
71\end{array}$ & $\begin{array}{l}5 / 273.7 \\
2 / 122.5 \\
7 / 110.8 \\
2 / 26.0\end{array}$ & $\begin{array}{l}1.8(0.6,4.3) \\
1.6(0.2,5.9) \\
6.3(2.5,13.0) \\
7.7(0.9,27.8)\end{array}$ & $\begin{array}{l}1 / 274.0 \\
1 / 122.8 \\
2 / 112.3 \\
0 / 26.6\end{array}$ & $\begin{array}{l}0.4(0.0,2.0) \\
0.8(0.0,4.5) \\
1.8(0.2,6.4) \\
0.0(N A, 13.9)\end{array}$ & $\begin{array}{l}0 / 274.1 \\
1 / 123.0 \\
1 / 112.4 \\
0 / 26.6\end{array}$ & $\begin{array}{l}0.0(\mathrm{NA}, 1.4) \\
0.8(0.0,4.5) \\
0.9(0.0,5.0) \\
0.0(\mathrm{NA}, 13.9)\end{array}$ \\
\hline \multicolumn{9}{|l|}{ All GMB exposure } \\
\hline All GMB Exposure & $\begin{array}{l}<42 \\
42 \text { to }<50 \\
50 \text { to }<60 \\
60 \text { to } \leq 65\end{array}$ & $\begin{array}{l}1295 \\
599 \\
538 \\
154\end{array}$ & $\begin{array}{l}13 / 713.6 \\
7 / 360.1 \\
14 / 311.7 \\
5 / 89.5\end{array}$ & $\begin{array}{l}1.8(1.0,3.1) \\
1.9(0.8,4.0) \\
4.5(2.5,7.5) \\
5.6(1.8,13.0)\end{array}$ & $\begin{array}{l}2 / 717.6 \\
1 / 362.1 \\
3 / 314.8 \\
0 / 91.4\end{array}$ & $\begin{array}{l}0.3(0.0,1.0) \\
0.3(0.0,1.5) \\
1.0(0.2,2.8) \\
0.0(\mathrm{NA}, 4.0)\end{array}$ & $\begin{array}{l}0 / 718.4 \\
1 / 361.6 \\
2 / 314.8 \\
0 / 91.4\end{array}$ & $\begin{array}{l}0.0(\mathrm{NA}, 0.5) \\
0.3(0.0,1.5) \\
0.6(0.1,2.3) \\
0.0(\mathrm{NA}, 4.0)\end{array}$ \\
\hline
\end{tabular}

Abbreviations: All GMB Exposure Patients treated with any GMB dose in any duration, $C$ Confidence interval, EAIR Exposure-adjusted incidence rate, GMB Galcanezumab, NA Not applicable, Phase 3_Pooled all patients from the 3 placebo-controlled phase 3 trials, SMQ Standardized Medical Dictionary for Regulatory Activities query, TEAE Treatment-emergent adverse event, TPY Total patient years at risk

${ }^{\text {a }} \mathrm{MMQ}$ search included only narrow terms

diastolic $(p=0.734)$ high $\mathrm{BP}$ in the double-blind treatment phase set, indicating that higher incidence rates of high BP in the older age groups are an effect of age rather than treatment.

\section{Discussion}

Several reports have shown that the clinical characteristics of migraine, such as attack severity and disease profile, can be different in older patients $[10,15,16]$. As a person with migraine ages, their brain can be metabolically and physically altered due to their disease [22-24]. Furthermore, age can influence patient behavior in a clinical trial. For example, a trial evaluating rizatriptan for the acute treatment of migraine found that older patients had lower responses to placebo [25].

Evaluation of baseline characteristics showed some differences between age groups. Interestingly, in patients with either episodic or chronic migraine, the $\leq 40$ age group had, on average, fewer monthly migraine headache days with acute medication use than did patients in the three older groups, even though the $\leq 40$ age group did not have fewer monthly migraine headache days on average. However, the youngest patient group had approximately seven monthly migraine headache days with acute medication, while the two middle age groups had means close to 8 and the oldest group had a mean of

Table 6 High blood pressure by age group

\begin{tabular}{|c|c|c|c|c|c|c|}
\hline \multirow[b]{2}{*}{ Dose Group } & \multirow[b]{2}{*}{ Age Group (years) } & \multirow[b]{2}{*}{ N } & \multicolumn{2}{|c|}{ Systolic Blood Pressure Higha } & \multicolumn{2}{|c|}{ Diastolic Blood Pressure High ${ }^{\mathrm{b}}$} \\
\hline & & & $\mathrm{n} / \mathrm{TPY}$ & EAIR (95\% Cl) & $\mathrm{n} / \mathrm{TPY}$ & EAIR $(95 \% \mathrm{Cl})$ \\
\hline \multicolumn{7}{|c|}{ Double-blind treatment phase } \\
\hline Phase 3_Pooled Placebo & $\begin{array}{l}<42 \\
42 \text { to }<50 \\
50 \text { to }<60 \\
60 \text { to } \leq 65\end{array}$ & $\begin{array}{l}656 \\
354 \\
305 \\
95\end{array}$ & $\begin{array}{l}10 / 244.4 \\
11 / 134.2 \\
16 / 109.9 \\
5 / 33.3\end{array}$ & $\begin{array}{l}4.1(2.0,7.5) \\
8.2(4.1,14.7) \\
14.6(8.3,23.7) \\
15.0(4.9,35.0)\end{array}$ & $\begin{array}{l}31 / 240.6 \\
33 / 131.4 \\
28 / 109.0 \\
7 / 32.2\end{array}$ & $\begin{array}{l}12.9(8.8,18.3) \\
25.1(17.3,35.3) \\
25.7(17.1,37.1) \\
21.7(8.7,44.8)\end{array}$ \\
\hline Phase 3_Pooled GMB & $\begin{array}{l}<42 \\
42 \text { to }<50 \\
50 \text { to }<60 \\
60 \text { to } \leq 65\end{array}$ & $\begin{array}{l}728 \\
321 \\
295 \\
70\end{array}$ & $\begin{array}{l}16 / 269.5 \\
8 / 121.6 \\
20 / 109.1 \\
4 / 25.6\end{array}$ & $\begin{array}{l}5.9(3.4,9.6) \\
6.6(2.8,13.0) \\
18.3(11.2,28.3) \\
15.6(4.3,40.0)\end{array}$ & $\begin{array}{l}43 / 265.4 \\
31 / 117.4 \\
25 / 108.5 \\
9 / 25.3\end{array}$ & $\begin{array}{l}16.2(11.7,21.8) \\
26.4(17.9,37.5) \\
23.0(14.9,34.0) \\
35.6(16.3,67.6)\end{array}$ \\
\hline \multicolumn{3}{|c|}{ Treatment-by-age group interaction $p$-value } & & 0.802 & & 0.734 \\
\hline \multicolumn{7}{|l|}{ All GMB exposure } \\
\hline All GMB Exposure & $\begin{array}{l}<42 \\
42 \text { to }<50 \\
50 \text { to }<60 \\
60 \text { to } \leq 65\end{array}$ & $\begin{array}{l}1268 \\
598 \\
530 \\
152\end{array}$ & $\begin{array}{l}32 / 703.9 \\
28 / 350.1 \\
42 / 299.7 \\
13 / 87.3\end{array}$ & $\begin{array}{l}4.6(3.1,6.4) \\
8.0(5.3,11.6) \\
14.0(10.1,18.9) \\
14.9(7.9,25.5)\end{array}$ & $\begin{array}{l}92 / 685.0 \\
77 / 332.1 \\
58 / 293.9 \\
17 / 85.0\end{array}$ & $\begin{array}{l}13.4(10.8,16.5) \\
23.2(18.3,29.0) \\
19.7(15.0,25.5) \\
20.0(11.7,32.0)\end{array}$ \\
\hline
\end{tabular}

Abbreviations: All GMB Exposure Patients treated with any GMB dose in any duration, $\mathrm{Cl}$ Confidence interval, EAIR Exposure-adjusted incidence rate, GMB

Galcanezumab, Phase 3_Pooled All patients from the 3 placebo-controlled phase 3 trials, TPY Total patient years at risk

${ }^{a}$ High systolic blood pressure is defined as any postbaseline measurement $\geq 140 \mathrm{mmHg}$ and $\mathrm{a} \geq 20 \mathrm{mmHg}$ increase from baseline

${ }^{b}$ High diastolic blood pressure is defined as any postbaseline measurement $\geq 90 \mathrm{mmHg}$ and $\mathrm{a} \geq 10 \mathrm{mmHg}$ increase from baseline 
about 7.5 day; hence, the difference in acute medication use may not be clinically significant.

Age may affect rates of lymph flow and endocytosis, which can result in reduced absorption, distribution, or elimination of a mAb [26]. Pharmacokinetic studies with mAbs show mixed results regarding the effect of age, but limited data exist for young and elderly populations [27-31]. This analysis indicated that there was a minor reduction in $\mathrm{CL} / \mathrm{F}$ with increasing age up to 65 years with no reduction in CL/F IIV. These findings suggest that dosing adult patients based on age to limit exposure variability would not be warranted for galcanezumab, and as such, per the product label, galcanezumab can be administered irrespective of age in an adult population $[1,2]$. This study's finding that age did not meaningfully influence blood concentrations of galcanezumab is consistent with no differential treatment effect in older age subgroups.

Elimination of a mAb from the body can occur by intracellular catabolism within the liver and kidney [32], so it is possible that mAb elimination may be altered in older patients since increasing age is associated with decreases in kidney and liver functions [12]. However, other organs including skin, muscle, and intestine are also involved in mAb degradation [32], thereby, possibly mitigating effects on $\mathrm{mAb}$ elimination due to renal or hepatic insufficiency. A previous study evaluated creatinine clearance, a measure of kidney function, and bilirubin concentration, a marker of liver function, across healthy adults and patients with migraine up to 65 years [20]. Results showed that the CL/F of galcanezumab was not affected by creatinine clearance (median: $111 \mathrm{~mL} /$ min (data on file); range: $24-308 \mathrm{~mL} / \mathrm{min}$ ) or bilirubin concentration (median: $7 \mu \mathrm{mol} / \mathrm{L}$ (data on file); range $2-$ $46 \mu \mathrm{mol} / \mathrm{L}$ ) [20]. Since most patients had normal to slightly above normal creatinine clearance and bilirubin levels, the effect of a more severe kidney or liver condition on galcanezumab PK in patients with migraine could not be sufficiently ascertained by this analysis.

Galcanezumab outperformed placebo on all efficacy measures, regardless of disease subtype and age group, although the treatment difference within age groups did not always reach statistical significance. In the chronic migraine $>50$ to $\leq 55$ age group, differences in efficacy between placebo and galcanezumab treatment were not statistically significant. This lack of significance was not likely due to advanced age because differences were significant for the older group ( $>55$ to $\leq 65$ years) in chronic migraine but might have been due to a relatively high level of response to placebo treatment in this age group. In the efficacy analyses, the placebo response varied among age groups but without any trend that would suggest a clear relationship with age and was likely due to random variability.
In addition, differences between placebo and galcanezumab treatment in $\geq 75 \%$ response in chronic migraine were not significant for some age groups. Patients with chronic migraine had a mean baseline of approximately 19 monthly migraine headache days. Therefore, a decrease of $\geq 75 \%$ was a higher hurdle for this group compared to patients with episodic migraine, resulting in relatively smaller numbers of patients included in these calculations. Despite lack of statistical significance in some measures in patients with chronic migraine, there did not appear to be any trend suggesting that increasing age was associated with decrease in effect.

Results on the incidence rates for TEAEs, SAEs, and DCAEs showed a significant treatment-by-age group interaction only for DCAEs, but with no clear trend by age group to indicate that older age was associated with increased risk of discontinuing treatment due to an adverse event.

While incidence rates for hypertension, as well as for high systolic and diastolic BP, were higher in older patients, comparisons between placebo- and galcanezumab-treated patients showed that galcanezumab treatment did not increase the chance of these cardiac-related TEAEs.

The aim of this study was to investigate the PK, efficacy, and safety of galcanezumab in older patients. However, patients over the age of 55 years made up a relatively small fraction of the total patients enrolled in the included studies. Of the 2886 patients in the placebo-controlled phase 3 trials, 357 (12.4\%) were between the ages of 55 and 65 years and $167(5.8 \%)$ patients were over 60 years of age. The inclusion of three additional trials in the safety data contributed another 83 galcanezumab-treated patients between 60 and 65 years to these analyses. Despite making up a smaller portion of the trial patients, we believe that the numbers of patients in the older age groups were sufficient to demonstrate maintained efficacy of galcanezumab in older patients, as well as support a level of safety equal to that seen in younger patients.

While migraine can be experienced by people of all ages $[7,10]$, the studies analyzed here enrolled patients with a maximum age of 65 years. However, the safety of galcanezumab in an older population was also addressed in a previous study of galcanezumab in patients with osteoarthritis. This earlier study enrolled patients between 40 and 75 years of age, with a mean age of 59 years, which is almost 18 years older than the mean age for patients enrolled in the placebo-controlled episodic and chronic migraine trials. Despite the inclusion of older patients in the osteoarthritis study, galcanezumab treatment was not associated with any changes in diastolic or systolic BP or clinically significant changes in safety laboratory tests [33]. 
Another limitation of this study is that patients with acute cardiovascular events within 6 months of screening, including those who had experienced stroke, myocardial infarction, unstable angina, percutaneous coronary intervention, coronary artery bypass graft, deep vein thrombosis/pulmonary embolism, or had planned cardiovascular surgery or percutaneous coronary angioplasty, or other serious cardiovascular risks were not included in these galcanezumab clinical trials. Older people, including those with migraine, especially those over the age of 65 years, have a higher risk of serious cardiovascular events [34], and this study was not able to consider patients with these medical conditions.

Age was not a stratification factor in any of the placebo-controlled phase 3 trials, so there are some imbalances of age subgroups across the treatment arms in these trials in episodic and chronic migraine. However, imbalances are expected to be mitigated by randomization, and the analyses by age appropriately account for the age main effect in the model to avoid any potential confounding. The relatively small sample size of some age subgroups potentially limited the power of the analyses, and this limitation may account for the lack of significance seen in some comparisons, particularly in the analyses of chronic migraine outcomes.

\section{Conclusions}

Overall, there was no indication that patient age (up to 65 years) affects efficacy of galcanezumab in migraine prevention, nor does it influence galcanezumab PK to an extent that would necessitate age-related dose adjustment. Furthermore, older patients did not experience increases in frequency of adverse events or increases in BP when treated with galcanezumab as compared with placebo.

\section{Abbreviations \\ BP: Blood pressure; CGRP: Calcitonin gene-related peptide; CL/F: Apparent clearance; DCAE: Discontinuation due to adverse event; EAIR: Exposure- adjusted incidence rate; IIV: Inter-individual variability; mAb: Monoclonal antibody; MIDAS: Migraine Disability Assessment; MOF: Model of the objective function; MSQ: Migraine-Specific Quality-of-life Questionnaire v2.1; PGI-S: Patient global impression of severity; PK: Pharmacokinetics; SAE: Serious adverse event; SMQ: Standardized Medical Dictionary for Regulatory Activities query; TEAE: Treatment-emergent adverse event; V/ F: Apparent volume of distribution.}

\section{Acknowledgements}

The authoring team would like to thank Shufang Wang for critical contributions to the conception and design of analyses used in this study.

\section{Authors' contributions}

VLS, PK, WK and AC participated in the conception and design of the work. IT participated in data acquisition. PK performed the statistical analyses for safety and efficacy outcomes, WK and TQ performed pharmacokinetic analyses, and VLS, IT, PK, WK, KD, MP, TQ and AC participated in analysis and interpretation of the data. VLS, PK, WK and MP were major contributors for the drafting of the manuscript and VLS, IT, PK, WK, KD, MP, TQ and AC revised the work for intellectual content. All authors read and approved the final manuscript.
Funding

The EVOLVE-1, EVOLVE-2, REGAIN, CGAB, and CGAJ trials were sponsored by Eli Lilly and Company. The ART-01 trial was sponsored by Arteaus Therapeutics.

\section{Availability of data and materials}

Lilly provides access to all individual participant data collected during the trial, after anonymization, with the exception of pharmacokinetic or genetic data. Data are available to request 6 months after the indication studied has been approved in the US and EU and after primary publication acceptance, whichever is later. No expiration date of data requests is currently set once data are made available. Access is provided after a proposal has been approved by an independent review committee identified for this purpose and after receipt of a signed data sharing agreement. Data and documents, including the study protocol, statistical analysis plan, clinical study report, blank or annotated case report forms, will be provided in a secure data sharing environment. For details on submitting a request, see the instructions provided at www.vivli.org.

\section{Ethics approval and consent to participate}

Appropriate institutional review boards at each study site reviewed and approved the study protocols. All studies were conducted according to the Declaration of Helsinki guidelines and Good Clinical Practice. Patients gave written, informed consent before participating in study procedures.

\section{Consent for publication}

Not applicable.

\section{Competing interests}

VLS is an employee of Eli Lilly and Company and/or one of its subsidiaries, Indianapolis, IN, USA and is a minor stockholder of Eli Lilly and Company. IT has received grants from Allergan, Amgen, Biohaven, ElectroCore, Eli Lilly and Company, Lundbeck (Alder), Nerivio, and Teva. He has received payments for speaking and/or consulting from Allergan, Amgen, Biohaven, Eli Lilly and Company, Lundbeck, Headache Cooperative of New England, Nerivio, Novartis, Revance, Teva, and The Headache Institute. IT received nonfinancial support from Eli Lilly and Company.

PK is an employee of Eli Lilly and Company and/or one of its subsidiaries, Indianapolis, IN, USA and is a minor stockholder of Eli Lilly and Company. WK is an employee of Eli Lilly and Company and/or one of its subsidiaries, Indianapolis, IN, USA and is a minor stockholder of Eli Lilly and Company. $\mathrm{KD}$ is an employee of Eli Lilly and Company and/or one of its subsidiaries, Indianapolis, IN, USA and is a minor stockholder of Eli Lilly and Company. MP is an employee of Eli Lilly and Company and/or one of its subsidiaries, Indianapolis, IN, USA and is a minor stockholder of Eli Lilly and Company. TQ is an employee of Eli Lilly and Company and/or one of its subsidiaries, Indianapolis, IN, USA and is a minor stockholder of Eli Lilly and Company. AC is an employee of Eli Lilly and Company and/or one of its subsidiaries, Indianapolis, IN, USA and is a minor stockholder of Eli Lilly and Company.

\section{Author details}

${ }^{1}$ Lilly Research Laboratories, Lilly Corporate Center, Indianapolis, IN, USA. ${ }^{2}$ Center for Headache Care and Research, Island Neurological Associates, a division of ProHEALTHcare Associates, Plainview, NY, USA. ${ }^{3}$ Eli Lilly Italia, Sesto Fiorentino, Italy.

Received: 1 April 2020 Accepted: 9 June 2020

Published online: 23 June 2020

References

1. Eli Lilly and Company. Emgality Highlights of Prescribing Information. 2018. http://accessdata.fda.gov/drugsatfda_docs/label/2018/761063s000lbl.pdf. Accessed 17 May 2020

2. Eli Lilly and Company. Emgality Summary of Product Characteristics. 2018. http://ema.europa.eu/en/medicines/human/EPAR/emgality. Accessed 17 May 2020

3. Stauffer VL, Dodick DW, Zhang Q, Carter JN, Ailani J, Conley RR (2018) Evaluation of Galcanezumab for the prevention of episodic migraine: the EVOLVE-1 randomized clinical trial. JAMA Neurol 75(9):1080-1088

4. Skljarevski V, Matharu M, Millen BA, Ossipov MH, Kim BK, Yang JY (2018) Efficacy and safety of galcanezumab for the prevention of episodic 
migraine: results of the EVOLVE-2 phase 3 randomized controlled clinical trial. Cephalalgia. 38(8):1442-1454

5. Detke HC, Goadsby PJ, Wang S, Friedman DI, Selzler KJ, Aurora SK (2018) Galcanezumab in chronic migraine: the randomized, double-blind, placebocontrolled REGAIN study. Neurology. 91(24):e2211-e2e21

6. Lipton RB, Bigal ME (2005) Migraine: epidemiology, impact, and risk factors for progression. Headache. 45(Suppl 1):S3-S13

7. Haan J, Hollander J, Ferrari MD (2007) Migraine in the elderly: a review. Cephalalgia. 27(2):97-106

8. Mattsson P, Svardsudd K, Lundberg PO, Westerberg CE (2000) The prevalence of migraine in women aged 40-74 years: a population-based study. Cephalalgia. 20(10):893-899

9. Prencipe M, Casini AR, Ferretti C, Santini M, Pezzella F, Scaldaferri N et al (2001) Prevalence of headache in an elderly population: attack frequency, disability, and use of medication. J Neurol Neurosurg Psychiatry 70(3):377-381

10. Wijeratne T, Tang HM, Crewther D, Crewther S (2019) Prevalence of migraine in the elderly: a narrated review. Neuroepidemiology. 52(1-2):104-110

11. Herrero S, Guerrero AL, Ruiz M, Pedraza Ml, Mulero P, Barón J et al (2013) Migraine in the elderly: clinical characteristics in a series of 71 cases. J Headache Pain 14(1):P152

12. Mangoni AA, Jackson SH (2004) Age-related changes in pharmacokinetics and pharmacodynamics: basic principles and practical applications. Br J Clin Pharmacol 57(1):6-14

13. Gonzalez-Hernandez A, Marichal-Cancino BA, MaassenVanDenBrink A, Villalon CM (2018) Side effects associated with current and prospective antimigraine pharmacotherapies. Expert Opin Drug Metab Toxicol 14(1):25-41

14. Russell FA, King R, Smillie SJ, Kodji X, Brain SD (2014) Calcitonin gene-related peptide: physiology and pathophysiology. Physiol Rev 94(4):1099-1142

15. Kelman $L$ (2006) Migraine changes with age: IMPACT on migraine classification. Headache. 46(7):1161-1171

16. Bigal ME, Lipton RB (2006) Migraine at all ages. Curr Pain Headache Rep 10(3):207-213

17. Dodick DW, Goadsby PJ, Spierings EL, Scherer JC, Sweeney SP, Grayzel DS (2014) Safety and efficacy of LY2951742, a monoclonal antibody to calcitonin gene-related peptide, for the prevention of migraine: a phase 2 , randomised, double-blind, placebo-controlled study. Lancet Neurol 13(9): 885-892

18. Skljarevski V, Oakes TM, Zhang Q, Ferguson MB, Martinez J, Camporeale A et al (2018) Effect of different doses of Galcanezumab vs placebo for episodic migraine prevention: a randomized clinical trial. JAMA Neurol 75(2): 187-193

19. Camporeale A, Kudrow D, Sides R, Wang S, Van Dycke A, Selzler KJ et al (2018) A phase 3, long-term, open-label safety study of Galcanezumab in patients with migraine. BMC Neurol 18(1):188

20. Kielbasa W, Quinlan T (2020) Population pharmacokinetics of Galcanezumab, an anti-CGRP antibody, following subcutaneous dosing to healthy individuals and patients with migraine. J Clin Pharmacol 60(2):229-239

21. Blumenfeld AM, Varon SF, Wilcox TK, Buse DC, Kawata AK, Manack A et al (2011) Disability, HRQoL and resource use among chronic and episodic migraineurs: results from the international burden of migraine study (IBMS). Cephalalgia. 31(3):301-315

22. Chong CD, Dodick DW, Schlaggar BL, Schwedt TJ (2014) Atypical agerelated cortical thinning in episodic migraine. Cephalalgia. 34(14):1115-1124

23. Lisicki M, D'Ostilio K, Coppola G, Parisi V, de Noordhout AM, Magis D et al (2019) Age related metabolic modifications in the migraine brain. Cephalalgia. 39(8):978-987

24. Neeb L, Bastian K, Villringer K, Israel H, Reuter U, Fiebach JB (2017) Structural gray matter alterations in chronic migraine: implications for a progressive disease? Headache. 57(3):400-416

25. Ho TW, Fan X, Rodgers A, Lines CR, Winner P, Shapiro RE (2009) Age effects on placebo response rates in clinical trials of acute agents for migraine: pooled analysis of rizatriptan trials in adults. Cephalalgia. 29(7):711-718

26. Mould DR, Meibohm B (2016) Drug development of therapeutic monoclonal antibodies. BioDrugs. 30(4):275-293

27. Muralidharan KK, Kuesters G, Plavina T, Subramanyam M, Mikol DD, Gopal S et al (2017) Population pharmacokinetics and target engagement of Natalizumab in patients with multiple sclerosis. J Clin Pharmacol 57(8):10171030

28. Long A, Chigutsa E, Wallin J (2017) Population pharmacokinetics of Necitumumab in Cancer patients. Clin Pharmacokinet 56(5):505-514
29. Zhang Y, Wei X, Bajaj G, Barrett JS, Meibohm B, Joshi A et al (2015) Challenges and considerations for development of therapeutic proteins in pediatric patients. J Clin Pharmacol 55(Suppl 3):S103-S115

30. Shemesh CS, Chanu P, Jamsen K, Wada R, Rossato G, Donaldson F et al (2019) Population pharmacokinetics, exposure-safety, and immunogenicity of atezolizumab in pediatric and young adult patients with cancer. J Immunother Cancer 7(1):314

31. Edlund H, Melin J, Parra-Guillen ZP, Kloft C (2015) Pharmacokinetics and pharmacokinetic-pharmacodynamic relationships of monoclonal antibodies in children. Clin Pharmacokinet 54(1):35-80

32. Ferri N, Bellosta S, Baldessin L, Boccia D, Racagni G, Corsini A (2016) Pharmacokinetics interactions of monoclonal antibodies. Pharmacol Res 111 592-599

33. Jin Y, Smith C, Monteith D, Brown R, Camporeale A, McNearney TA et al (2018) CGRP blockade by galcanezumab was not associated with reductions in signs and symptoms of knee osteoarthritis in a randomized clinical trial. Osteoarthr Cartil 26(12):1609-1618

34. Paneni F, Diaz Canestro C, Libby P, Luscher TF, Camici GG (2017) The aging cardiovascular system: understanding it at the cellular and clinical levels. J Am Coll Cardiol 69(15):1952-1967

\section{Publisher's Note}

Springer Nature remains neutral with regard to jurisdictional claims in published maps and institutional affiliations.
Ready to submit your research? Choose BMC and benefit from:

- fast, convenient online submission

- thorough peer review by experienced researchers in your field

- rapid publication on acceptance

- support for research data, including large and complex data types

- gold Open Access which fosters wider collaboration and increased citations

- maximum visibility for your research: over $100 \mathrm{M}$ website views per year

At BMC, research is always in progress.

Learn more biomedcentral.com/submissions 